\title{
Establishment and persistence of seep vestimentiferan aggregations on the upper Louisiana slope of the Gulf of Mexico
}

\author{
Derk C. Bergquist* ${ }^{*}$ Istvan A. Urcuyo**, Charles R. Fisher \\ The Pennsylvania State University, Department of Biology, 208 Mueller Laboratory, University Park, Pennsylvania 16802, USA
}

\begin{abstract}
This study investigated the population size structures, growth rates and ages of 2 coexisting vestimentiferan tubeworms (Lamellibrachia cf. luymesi and Seepiophila jonesi) at hydrocarbon seeps in the Gulf of Mexico in order to determine the factors contributing to their establishment and persistence. Population size structures of 12 complete aggregations indicated that both vestimentiferans recruit roughly simultaneously during the early stages of aggregation development, after which time recruitment largely ceases. By staining the vestimentiferan tubes in situ and measuring subsequently deposited tube material between 1 and 3 yr later, we found that $L$. cf luymesi grew faster than $S$. jonesi overall and within individual aggregations. Using the relationship between growth rate and length for each species we also showed that the mean ages and age ranges of individuals of both species were very similar in younger aggregations. A long life span appears to be characteristic of vestimentiferans at these seep sites. Staining, redeployment and subsequent collection of 2 small clusters of vestimentiferans showed that above their point of attachment to the solid substrate, these species elongate their tubes only at the anterior-most end. These species also possess the ability to elongate their tubes in a posterior direction below their point of attachment to the solid substrate. In these seep vestimentiferans, a combination of spatial and temporal limitation of suitable settlement sites may have driven the evolution of a long life span over which reproduction may occur many times.
\end{abstract}

KEY WORDS: Recruitment $\cdot$ Life history $\cdot$ Cold seep $\cdot$ Vestimentiferans $\cdot$ Gulf of Mexico Resale or republication not permitted without written consent of the publisher

\section{INTRODUCTION}

Vestimentiferan tubeworms widely colonize both hydrothermal vent and cold seep environments where they often form dense aggregations of individuals that visually dominate the sessile macrofauna (Corliss et al. 1979, Paull et al. 1984, Kennicutt et al. 1985, Tunnicliffe 1991). Because vestimentiferans rely entirely upon intracellular, sulfide-oxidizing chemoautotrophic

Present addresses:

${ }^{*}$ University of Florida, Department of Fisheries and Aquatic Sciences, 7922 NW 71st Street, Gainesville, Florida 32653, USA.E-mail: derk@ufl.edu

** Department of Biology, Gettysburg College, Gettysburg, Pennsylvania 17325, USA bacteria for nutrition (Childress et al. 1984, 1991, Goffredi et al. 1999, Bright et al. 2000) and form highbiomass aggregations, they potentially represent an important component in the nutrient cycles of the larger vent or seep community. The entangled tubes of vestimentiferan aggregations also create a dense secondary structure that may provide a physical habitat for a wide range of additional species associated with these environments (Sarrazin \& Juniper 1999, Tsurumi \& Tunnicliffe 2001). Thus, the process by which vestimentiferans establish and maintain aggregations is likely to play an important role in the ecology of hydrothermal vent and cold seep systems.

Our current understanding of vestimentiferan biology stems largely from studies of the giant tubeworm Riftia pachyptila from hydrothermal vents on the East 
Pacific Rise. R. pachyptila lives in areas of diffuse hydrothermal vent flow and simultaneously obtains oxygen and sulfide to sustain the intact symbiosis by positioning its gas-exchange organ, the plume, in the zone where sulfidic vent effluent vigorously mixes with oxic bottom water (Arp et al. 1985). This species rapidly colonizes new vent openings and can grow extremely fast (depositing $85 \mathrm{~cm} \mathrm{yr}^{-1}$ of new tube), but later successional species replace it within just a few years (Hessler et al. 1988, Lutz et al. 1994, Shank et al. 1998).

Recent studies indicate that seep vestimentiferans are physiologically and ecologically different from their vent relatives; therefore generalizations based on vent species do not necessarily pertain to those found elsewhere. At hydrocarbon seep sites on the upper Louisiana slope, the vestimentiferans Lamellibrachia cf. luymesi (S. L. Gardiner, Bryn Mawr, pers. comm.) and a recently described species Seepiophila jonesi (Gardiner et al. 2001) co-occur in bush-like aggregations (Fig. 1) that commonly stand $2 \mathrm{~m}$ in height and reach several meters in diameter (MacDonald et al. 1989, 1990). These vestimentiferans obtain energy from sulfide produced as a by-product of bacterial hydrocarbon degradation beneath the sediment-water interface (Anderson et al. 1983, Sassen et al. 1993, Aharon \& Fu 2000). In contrast to the vent environment of Riftia pachyptila, little active mixing of seep fluids and bottom water occurs above the sediment-water interface around seep vestimentiferans. As a result, the plumes of adult $L$. cf. luymesi (which may be positioned more than $2 \mathrm{~m}$ above the seafloor) do not have

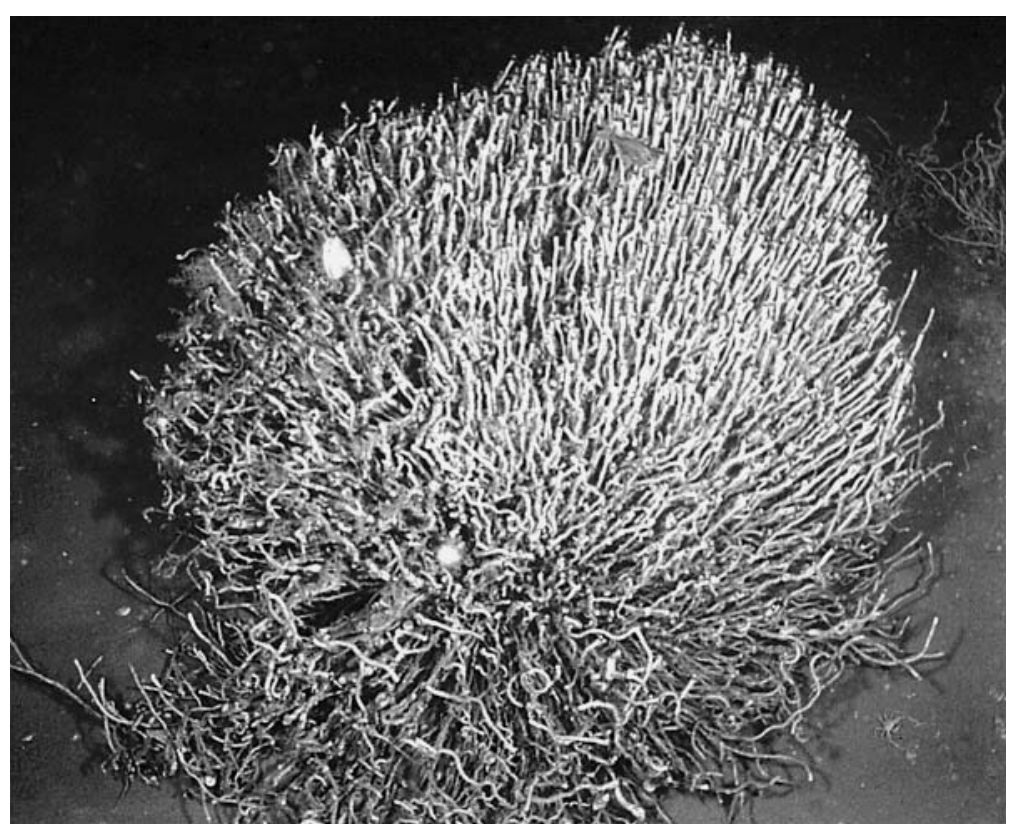

Fig. 1. Typical vestimentiferan aggregation on the upper Louisiana slope of the Gulf of Mexico access to significant amounts of hydrogen sulfide (MacDonald et al. 1989, Scott \& Fisher 1995, Julian et al. 1999, Freytag et al. 2001). Rather, current data indicates that $L$. cf. luymesi can obtain oxygen across its plume and sulfide across buried posterior extensions of its tube (Julian et al. 1999, Freytag et al. 2001). Studies of vestimentiferan communities on the upper Louisiana slope have suggested that larvae settle on exposed carbonate rock, also a by-product of bacterial hydrocarbon degradation (Behrens 1988), in areas where this hydrocarbon seepage is most vigorous (Simpkins 1994, Fisher et al. 1997). Also unlike R. pachyptila, L. cf. luymesi grows slowly and requires 170 to 250 years to attain a common adult size of $2 \mathrm{~m}$ (Fisher et al. 1997, Bergquist et al. 2000). Several investigators have also hypothesized that, over time, sediment buries the settlement substrate and seep fluid expression wanes at the sediment-water interface, eventually causing cessation of local recruitment (Simpkins 1994, Fisher et al. 1997). As the individuals within an aggregation grow, they extend their tubes upward and outward from the central point of attachment to the substrate, giving the aggregation a distinctive domed or bushlike profile.

In this study, we investigate the establishment and persistence of seep vestimentiferan aggregations using in situ growth rates, relative abundances and size structures of Lamellibrachia cf. luymesi and Seepiophila jonesi populations. This information allows us to examine (1) the relative timing of settlement between the 2 species, (2) whether or not settlement to a substrate is limited to a short period of time, and (3) the length of time over which this recruitment occurs. We further relate these findings to the mechanisms influencing vestimentiferan life history in the patchy seep environment.

\section{MATERIALS AND METHODS}

Vestimentiferan collections. This study was conducted at 2 sites within the Green Canyon Lease Area on the upper Louisiana slope in the Gulf of Mexico: Bush Hill $\left(27^{\circ} 46.96^{\prime} \mathrm{N}, 91^{\circ} 30.46^{\prime} \mathrm{W}\right.$; on the border of Green Canyon Leasing Blocks 184 and 185) and a site in Green Canyon leasing block $234\left(27^{\circ} 44.7^{\prime} \mathrm{N}, 91^{\circ} 13.3^{\prime} \mathrm{W}\right)$, both of which lie at a depth of approximately $540 \mathrm{~m}$. Vestimentiferans were collected in 1995, 1997 and 1998 using the manipulator of the Johnson Sea Link manned submersible (JSL, Harbor Branch Oceanographic Institution) and 3 
additional devices designed for the bulk collection of vestimentiferans: Bushmaster Jr., Bushmaster Sr., and the Lasso. The Bushmaster Jr. is a hydraulically actuated net, $67 \mathrm{~cm}$ in height and $70 \mathrm{~cm}$ in diameter, capable of enclosing and collecting entire aggregations of vestimentiferans without the loss of associated fauna. The Bushmaster Sr. is nearly identical, except that its dimensions are designed to accommodate a net $120 \mathrm{~cm}$ in height and $150 \mathrm{~cm}$ in diameter, which enable it to enclose and collect larger aggregations. The Lasso consists of 3 independently operated, hydraulic cylinders, each capable of cinching a large plastic cable tie ( $10 \mathrm{~cm}$ diameter when looped) around a cluster of tubeworms. Once a cable tie is securely closed around a group of vestimentiferans, it can be released from the cylinder and the sample collected with the manipulator of the submersible and placed in an insulated collection box. The advantage of this device is that up to 4 collections of stained vestimentiferans (3 cinched with cable ties and 1 without) can be made on the same dive and maintained as separate samples.

Twelve aggregations of a broad size range were collected for the analysis of population size structure during the course of this study. Following collection of each aggregation, we inspected each collection station for any remaining vestimentiferans. With the exception of 2 aggregations (GC-3 and GC-5), we collected all of the vestimentiferans present in each aggregation. When GC-3 was brought on board the ship, a visually distinct, second cluster of vestimentiferans was hanging from and partially entangled with 1 side of the aggregation of interest. This cluster was easily pulled free of the main body of the aggregation and processed separately. As the main aggregation and cluster were somewhat intertwined, such that the individuals comprising them overlapped, both were treated together as a whole aggregation to avoid personal bias when exploring size structure. GC-5 was a large-diameter aggregation composed of mostly prone individuals. As a result, the Bushmaster Sr. collection device could only enclose and retrieve 1 side (approximately onehalf) of the aggregation. Once on board ship, all vestimentiferans within each aggregation were identified to species and their anterior tube diameters and standardized tube lengths were measured. Standardized tube length was measured as the distance from the open anterior end of the tube to the point at which the roughly conical tube tapered to $2 \mathrm{~mm}$ in diameter. In one large aggregation (GC-4), all individuals were identified to species, but not all were measured. This aggregation was sub-sampled by haphazardly placing 6 plastic cable ties $(\sim 17 \mathrm{~cm}$ diameter loops $)$ near its base and measuring all individuals within the loops.

A chi-square test was used to determine whether the relative abundances of the 2 species were homogeneous across aggregations. Because homogeneity across aggregations was rejected $\left(\chi^{2}=116.5, \mathrm{df}=11, \mathrm{p}<0.001\right)$, the abundances of the 2 species were compared against expected 50:50 distributions within each individual aggregation using chi-square tests. To determine whether one species was significantly longer than the other, an ANOVA was employed with species as a fixed factor and aggregation as a blocking variable. The mean sizes of the 2 species within each aggregation were then compared using individual Student's $t$-tests. All multiple comparisons were corrected using the sequential Bonferroni method for independent comparisons (Rice 1989). Size distributions were constructed for each aggregation using only those individuals for which standardized length was obtained. Unfortunately, the collection of vestimentiferans was destructive, thus preventing the construction of size frequencies for sequential years from a single aggregation.

Analysis of growth. Vestimentiferans in 22 different aggregations of varying size (in terms of vestimentiferan length and abundance and total aggregation biomass) from 2 geographically separated sites were marked in 1994, 1995 and 1997 with an in situ staining device. The device consisted of a cylindrical, closed, top hood ( $25 \mathrm{~cm}$ in diameter) that was placed over the anterior ends of a cluster of tubeworms by the manipulator arm of the JSL. Once positioned, a positively buoyant, blue chitin stain (Acid Blue 158) was hydraulically pumped into the hood and allowed to bathe the tubes for 5 to $8 \mathrm{~min}$. The blue stain absorbed by the tubes was readily visible once the hood was raised. Video observations taken within hours of staining showed tube worms with their plumes extended like those of surrounding unstained individuals and with no signs of the stain having fouled their plumes or affected their behavior. Stained individuals were collected in subsequent field seasons and the inside anterior tube diameter, standardized tube length and linear tube growth of each were measured. Linear tube growth was measured as the length of the unstained portion between the anterior end of the tube and the stain mark. This was standardized to a yearly growth rate by dividing linear growth by the length of time between staining and collection for each stained cluster (at least $0.88 \mathrm{yr}$ and at most $1.89 \mathrm{yr}$ ).

To determine if there was a relationship between growth rate and initial tube length in Seepiophila jonesi, linear regression (Minitab 12.21, Minitab Inc.) was applied to the data. To correct for departures from normality, data were $\log$-transformed $(\log [x]$ and $\log [y+1])$ prior to analysis. Residuals of all analyses were examined for violations of general linear-model assumptions. The relationship between growth rate and tube length in Lamellibrachia cf. luymesi has been reported in Bergquist et al. (2000). 
Of the 22 aggregations in which vestimentiferans were stained, growth rate data were successfully collected for both Lamellibrachia cf. luymesi and Seepiophila jonesi concurrently in 8 aggregations. In order to determine whether the growth rates of the 2 species were significantly different, ANOVA was employed with 'species' as a fixed factor and 'aggregation' as a blocking variable. To test for within-aggregation growth rate differences between the 2 species, individual Student's $t$-tests and the sequential Bonferroni method were employed. In addition, 2 analyses were performed to ensure the staining process did not affect the mortality or growth rates of these vestimentiferans. A chi-square test was used to compare the numbers of living and dead vestimentiferans of each species (dead identified as empty tubes) between stained tubeworms and unstained tubeworms collected inadvertently with the stained individuals. We further compared the growth rate of $L$. cf. luymesi determined in Fisher et al. (1997) by a non-staining method (length range 98 to $216 \mathrm{~cm}$ ) to that estimated by the staining method here for $L$. cf. luymesi of the same size range.

To determine whether Lamellibrachia cf. luymesi and Seepiophila jonesi extend their tubes at any location other than at the anterior end, 2 small clusters of vestimentiferans containing both species were collected in June 1995 along with the portion of carbonate rock to which they were anchored. These were placed in a temperature-insulated acrylic box for transport to the surface and, once on board ship, were maintained in chilled seawater $\left(6^{\circ} \mathrm{C}\right)$. All exposed tube material in the 2 clusters was stained by entirely submerging them in a solution of Acid Blue 158 and chilled seawater. They were then deployed by the submersible in an area where vestimentiferans of approximately the same size were abundant (in the hope that sufficient sulfide was present to sustain the individuals we deployed). These clusters were retrieved in July 1997, preserved in $10 \%$ formalin, and later transferred to $70 \%$ ethanol. The entire tubes of all individuals were carefully inspected for unstained regions that would indicate growth of new tube material. Because of the manipulations necessary for this experiment, data from these clusters were not used in any other analyses. We have successfully maintained similar collections in chilled aquaria for $3 \mathrm{yr}$, and $L$. cf. luymesi and $S$. jonesi appear to be unaffected by the reduced pressure, although their growth in the laboratory is generally slow.

\section{RESULTS}

\section{Composition, size structure and age}

Both Lamellibrachia cf. luymesi and Seepiophila jonesi occurred in every aggregation that was collected intact. The abundances of the 2 species differed
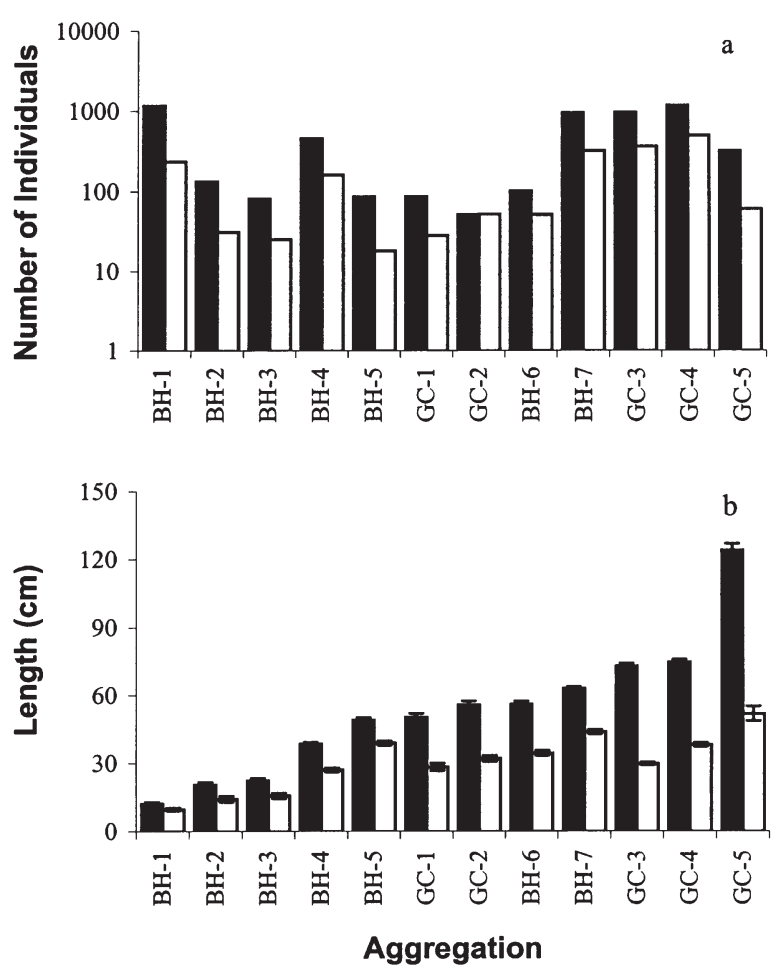

Fig. 2. Lamellibrachia cf. luymesi (closed bars) and Seepiophila jonesi (open bars) (a) Abundance of each species in 12 aggregations; between-species differences are significant in all aggregations except GC-2. Aggregations are ordered by increasing mean standardized tube length of $L$. cf. luymesi. (b) Mean standardized tube lengths (bars = $1 \mathrm{SE}$ ) in the same 12 aggregations; between-species differences were significant within all aggregations (BH-1: $\mathrm{p}=0.0126$; all other aggregations: $\mathrm{p}<0.0001)$

significantly from a 50:50 distribution $\left(\chi^{2} \leq 16.5\right.$, df $=1$, $\mathrm{p}<0.0001$ for each) within all aggregations except GC-2, the aggregation containing the fewest number of vestimentiferans. $L$. cf. luymesi was the more abundant species in all aggregations except GC-2 (Fig. 2a). Although the relative abundances of the 2 species varied among the different aggregations, the 2 species co-occur in similar proportions across aggregations of differing overall vestimentiferan abundance (Fig. 3).

The mean length of Lamellibrachia cf. luymesi was significantly greater than the mean length of Seepiophila jonesi in every aggregation (Fig. 2b). In Fig. 4, the size distributions of both species in each of 12 aggregations collected in their entirety have been placed in order of increasing mean $L$. cf. luymesi length to show a rough time series from presumably the youngest (smallest mean L. cf. luymesi length) to the oldest (largest mean L. cf. luymesi length). Two primary patterns emerge from this series of size frequencies. First, in several apparently younger aggregations, the smallest size classes of both species were present, and the 


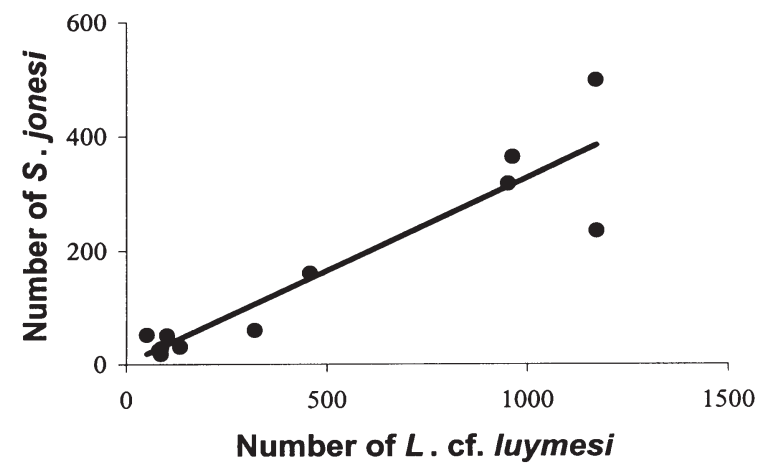

Fig. 3. Number of Seepiophila jonesi versus number of Lamellibrachia cf. luymesi in the 12 aggregations collected for the determination of population size structure. Regression equation: $y=0.39 x-17, R^{2}=0.95, p<0.001$. Each point on the graph represents a single aggregation size ranges of individuals present were similar between the 2 species (Fig. 4a-d). However, in older aggregations, the smallest size classes were largely absent or minimally represented, and $L$. cf. luymesi were on average much larger than $S$. jonesi (Fig. 4e-1). Second, as vestimentiferans within an aggregation grew, the difference between the lengths of the 2 species increased, and in many cases $S$. jonesi appeared to reach a limit to its size more quickly than L. cf. luymesi (Figs. 4 \& 5).

\section{Growth}

In previous work, we found that growth rate of Lamellibrachia cf. luymesi decreased as an exponential function of tube length (Fig. 6a) (Bergquist et al. 2000).
Fig. 4. Lamellibrachia cf. luymesi (closed bars) and Seepiophila jonesi (open bars). Size distributions in (a) $\mathrm{BH}-1$, (b) $\mathrm{BH}-2$, (c) $\mathrm{BH}-3$, (d) $\mathrm{BH}-4$, (e) BH-5, (f) GC-1, (g) GC-2, (h) BH-6, (i) BH-7, (j) GC-3, (k) GC-4, (l) GC-5. Aggregations are ordered by increasing mean standardized tube length of $L$. cf luymesi. Note different scales on $y$-axes

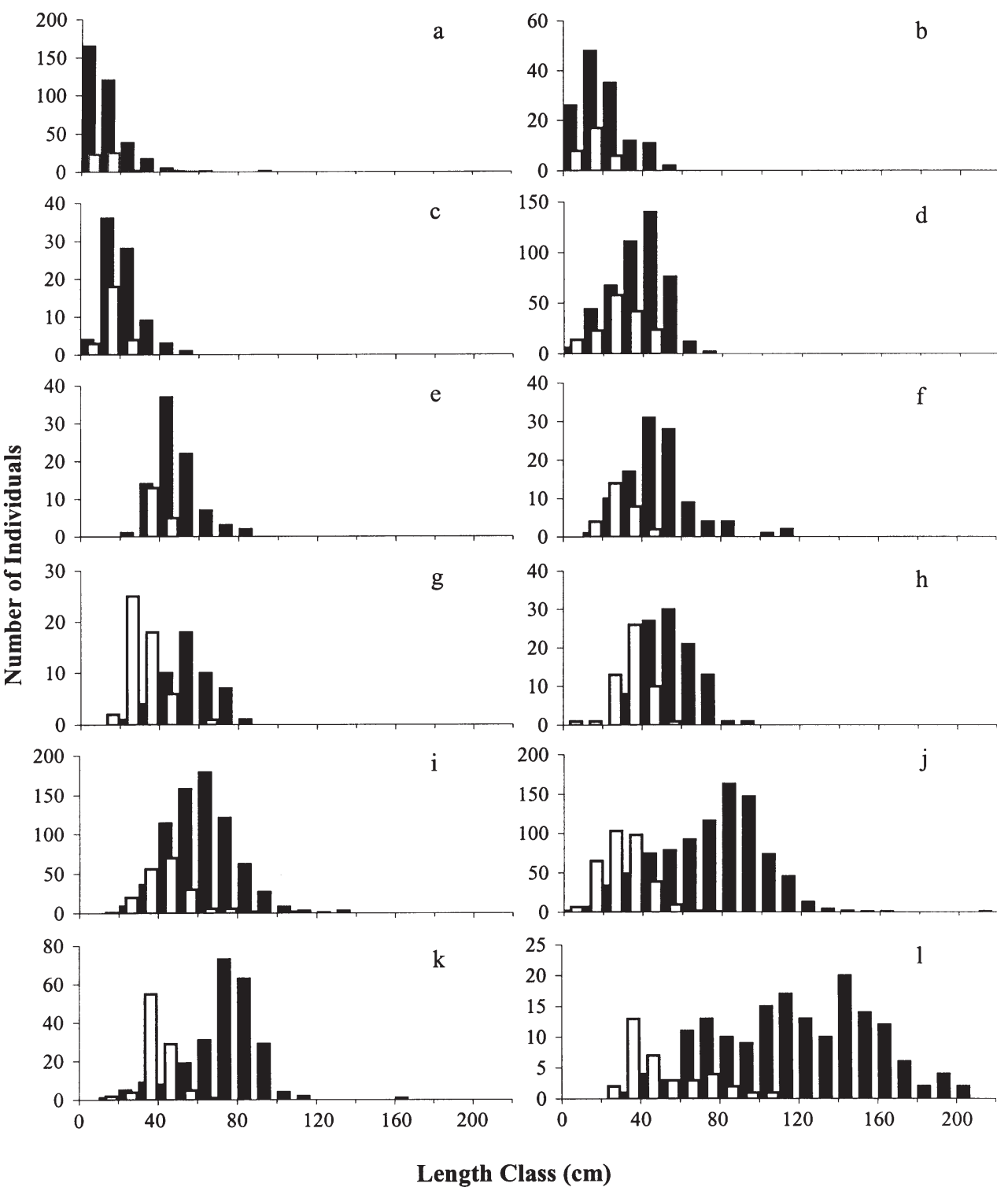




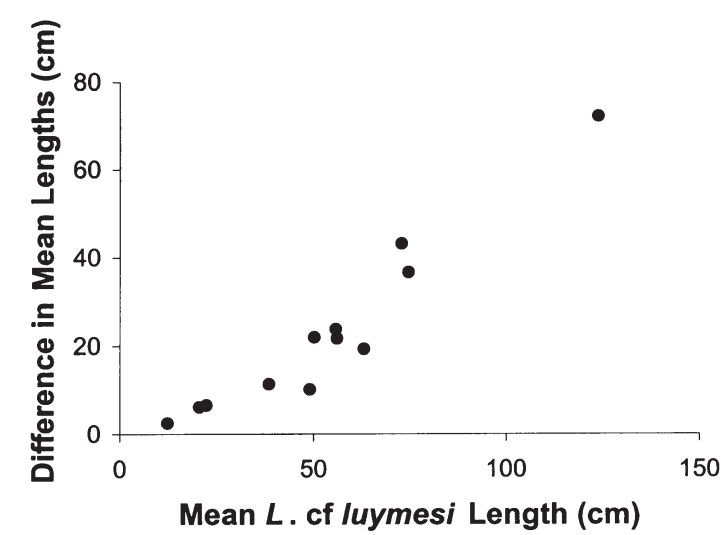

Fig. 5. Difference between mean Lamellibrachia cf. luymesi length and mean Seepiophila jonesi length as a function of mean $L$. cf. luymesi length in each aggregation. Note that the size difference between the 2 species increases as the tubeworms grow (and age)

The smallest individuals of this species $(0$ to $50 \mathrm{~cm}$ in length) displayed a maximum growth rate of $10 \mathrm{~cm}$ $\mathrm{yr}^{-1}$, but this maximum tapered to less than $3 \mathrm{~cm} \mathrm{yr}^{-1}$ by the time they reached $125 \mathrm{~cm}$ in length. Within the size range of Seepiophila jonesi collected in this study (5 to $50 \mathrm{~cm}$ in length), no significant relationship between growth rate and standardized tube length was identified ( $p>0.05$ for all models; Fig. 6b). The mean overall growth rate for all $S$. jonesi collected in this study was $2.19 \mathrm{~cm} \mathrm{yr}^{-1}(\mathrm{SE}=0.20, \mathrm{n}=80)$. The mean overall growth rate for all $L$. cf. luymesi in the 8 aggregations in which $S$. jonesi were also stained was $2.70 \mathrm{~cm} \mathrm{yr}^{-1}$ ( $\mathrm{SE}=0.10, \mathrm{n}=306$ ). Among those aggregations from which we successfully collected growth data on both species simultaneously, L. cf. luymesi was found to grow significantly faster than $S$. jonesi overall (blocked ANOVA: $F_{1,377}=12.19, \mathrm{p}=0.001$ ). Considering each of these aggregations individually, the mean growth rate

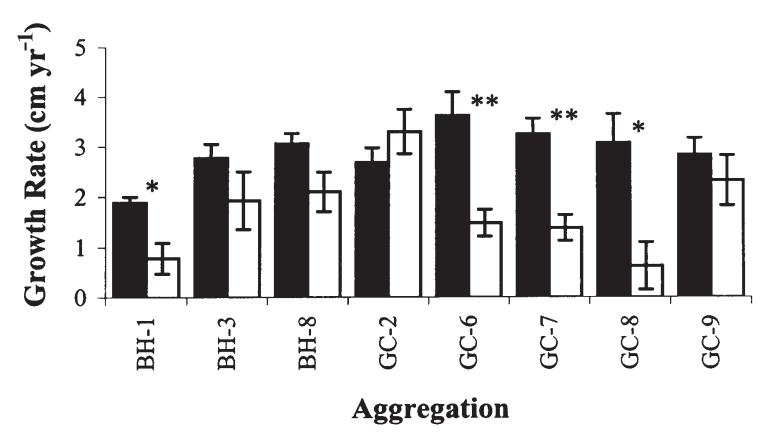

Fig. 7. Lamellibrachia cf. luymesi (closed bars) and Seepiophila jonesi (open bars). Mean growth rates (bars $=1 \mathrm{SE}$ ) in 8 aggregations for which data on both species were successfully collected. *Significantly different at individual $\mathrm{p}<0.05$, ${ }^{* *}$ significantly different after sequential Bonferroni correction

of $L$. cf. luymesi was significantly higher than that of $S$. jonesi in 4 aggregations before correcting for multiple comparisons and in 2 after employing a sequential Bonferroni correction (Fig. 7).

Two lines of evidence indicate that the staining process did not affect the growth or mortality of these vestimentiferans. The proportions of empty tubes (representing dead tubeworms) were less than $1 \%$ amongst stained individuals of both species $(0.7 \%$ in Lamellibrachia cf. luymesi; $0.0 \%$ in Seepiophila jonesi) and were similar to those of unstained vestimentiferans collected inadvertently with the stained individuals ( $L$. cf. luymesi $1.1 \%, \mathrm{n}=267$; S. jonesi $0.9 \%, \mathrm{n}=217$ ). The numbers of living and dead individuals were not significantly different between stained and unstained individuals (L. cf. luymesi: $\chi^{2}=0.32, \mathrm{p}>0.5 ;$. jonesi: $\chi^{2}$ $=0.74, \mathrm{p}>0.3$ ). The $L$. cf. luymesi growth rate calculated by Fisher et al. (1997) using a non-staining (banding) method (growth rate $=0.89 \mathrm{~cm} \mathrm{yr}^{-1}, \mathrm{SE}=0.35, \mathrm{n}=$ 8 , length range 98 to $216 \mathrm{~cm}$ ) was not significantly dif-
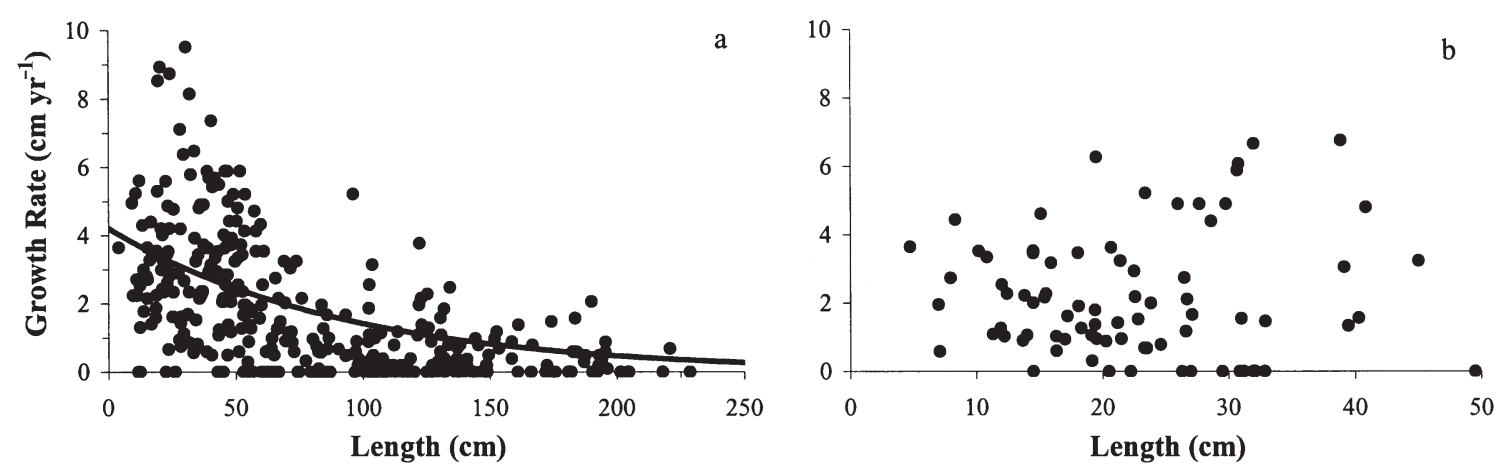

Fig. 6. (a) Lamellibrachia cf. luymesi (reprinted from Bergquist et al. 2000) and (b) Seepiophila jonesi. Relationship between yearly growth rate and standardized initial tube length. The L. cf. luymesi data set includes 599 individuals from 22 different aggregations, and the $S$. jonesi data set includes 79 individuals from 8 different aggregations. The $S$. jonesi data set is limited in size range due to staining and collection constraints (see 'Discussion') 
ferent than that calculated for individuals of the same size range using the staining methodology in this study (growth rate $=0.71, \mathrm{SE}=0.09, \mathrm{n}=137$; $t$-test: $t=0.26$, $\mathrm{p}=0.80)$.

Evidence of tube growth was apparent in 2 distinct regions of the small individuals in the aggregations that had been collected, entirely stained and then deployed for 2 yr. Above the point of attachment of the vestimentiferans' tubes to the carbonate substrate, the open anterior end of the tube was the only area showing evidence of elongation. Because these vestimentiferans occupy the entire lengths of their tubes, this finding indicates that anterior tube elongation reflects growth in all tubeworm tissues above the point of attachment. The tubes also showed evidence of elongation posterior to their point of attachment to the substrate. However, because this portion of tube is particularly thin-walled and fragile, unstained tube in this region was difficult to differentiate from the lightly stained portions. Also posterior to the attachment point, several individuals' tubes (but not the soft tissue inside) were bifurcated, further indicating that tube deposition was occurring in this region.

\section{DISCUSSION}

The presence of both species in all aggregations of small individuals that have been collected (and observed) to date indicates that the recruitment of Lamellibrachia cf. luymesi and Seepiophila jonesi to a particular substrate occurs within the same time frame in this area of the Gulf of Mexico. Although L. cf. luymesi is typically the numerical dominant within an individual aggregation, both species consistently recruit to different aggregations in similar proportions. The absence or great under-representation of the smallest size classes in aggregations containing larger individuals further indicates that recruitment of both species to a local substrate is temporally constrained to the early stages of aggregation development. Curiously, limited additional settlement may sometimes occur to the outside of living vestimentiferan tubes or to the inside of empty tubes (D.C.B. pers. obs.). However, such renewed settlement is rare and, when it occurs, is spatially constrained within the aggregation. For example, when the GC-3 aggregation was collected, a visually distinct, secondary cluster of vestimentiferans was hanging from and partially intertwined with 1 side of it. The secondary cluster was dominated by smaller individuals of both species, whereas the main aggregation was dominated by larger individuals (Fig. 8), suggesting 2 temporally distinct recruitment events. The abundance of both species in the secondary cluster also indicates that renewed recruitment to an

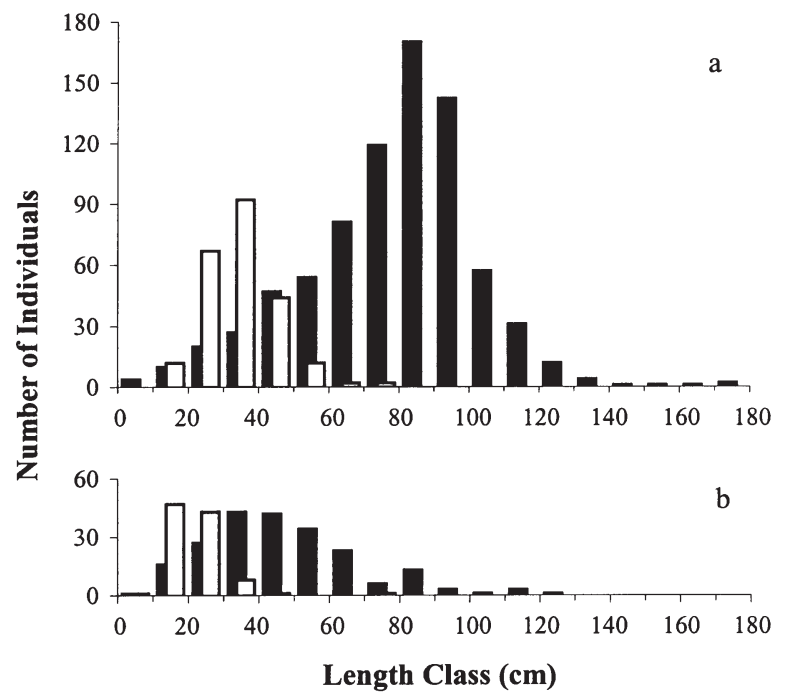

Fig. 8. Lamellibrachia cf. luymesi (closed bars) and Seepiophila jonesi (open bars). Size distributions in (a) the main body of Aggregation GC-3 and (b) the peripheral cluster collected with it

established aggregation is not limited to only 1 species.

In order to place rough constraints upon the period of time over which recruitment of the 2 species occurs, the age of each of the vestimentiferans in the 8 aggregations of the smallest individuals was estimated. For Lamellibrachia cf. luymesi we used the size-specific model $\left(\right.$ Age $\left.=21.8 \times\left[\mathrm{e}^{-0.0109 \times \text { Length }}-1\right]\right)$ derived by Bergquist et al. (2000) to estimate age, and for Seepiophila jonesi we used the mean growth rate calculated above (the mean growth rate was used because no size-specific trend in growth rate for this species was found within the size range collected). Ages were estimated only in the 8 aggregations in which no more than $1 \mathrm{~S}$. jonesi exceeded $50 \mathrm{~cm}$ in length to avoid bias from extrapolating outside the size range of size-specific growth rate data available for this species. For both species, mean age estimates and the 95\% quantiles of the age distributions (the range excluding the youngest $2.5 \%$ and oldest $2.5 \%$ of the individuals) within each aggregation were quite similar (Table 1). The age ranges indicate that recruitment of $95 \%$ of the individuals of both species within a single aggregation occurs over a period of roughly 8 to $25 \mathrm{yr}$, after which time additional new settlement largely ceases. The timing of settlement appears to be coincident in the 2 species; however, further studies will be necessary to determine whether differences in species-specific settlement timing exist in the very early stages of aggregation establishment. The rather large age range in Aggregation GC-1 resulted from the collection of some nearby larger individuals along with the intended aggregation (D.C.B. pers. obs.); these were included 
Table 1. Lamellibrachia cf. luymesi and Seepiophila jonesi. Mean estimated ages and $95 \%$ age quantiles for tubeworms in 8 aggregations. Minimum and maximum values of the $95 \%$ quantiles are shown; values in parentheses are numbers of years within the quantiles. Aggregations ordered by increasing mean length of $L$. cf. luymesi

\begin{tabular}{|lcccc|}
\hline Aggregation & \multicolumn{2}{c}{ L. cf. luymesi } & \multicolumn{2}{c|}{ S. jonesi } \\
& $\begin{array}{c}\text { Mean age } \\
(\mathrm{yr})\end{array}$ & $\begin{array}{c}\text { 95\% quantiles } \\
(\mathrm{yr})\end{array}$ & $\begin{array}{c}\text { Mean age } \\
(\mathrm{yr})\end{array}$ & $\begin{array}{c}\text { 95\% quantiles } \\
(\mathrm{yr})\end{array}$ \\
\hline BH-1 & 3 & $0-12(13)$ & 4 & $0-20(21)$ \\
BH-2 & 6 & $1-16(17)$ & 7 & $1-12(13)$ \\
BH-3 & 6 & $2-14(13)$ & 7 & $1-12(13)$ \\
BH-4 & 12 & $3-21(19)$ & 12 & $3-21(19)$ \\
BH-5 & 16 & $9-30(22)$ & 18 & $15-22(8)$ \\
GC-1 & 16 & $6-49(44)$ & 13 & $5-18(14)$ \\
GC-2 & 19 & $8-32(25)$ & 15 & $9-28(20)$ \\
BH-6 & 19 & $9-31(23)$ & 16 & $5-25(21)$ \\
\hline
\end{tabular}

in the analysis because they could not be definitively identified and removed after collection. The sizespecific growth rates from which ages were estimated reflect not only the effects of growth allometry but also among-aggregation environmental variability and temporal changes in resource availability that may occur as total aggregation biomass increases with continued vestimentiferan growth. As a result, the estimates reflect vestimentiferan growth and longevity under variable and dynamic in situ conditions.

Both of the seep vestimentiferans studied here have slow growth rates compared to that of the vent vestimentiferans Tevnia jerichonana $\left(30 \mathrm{~cm} \mathrm{yr}^{-1}\right)$ and Riftia pachyptila ( $85 \mathrm{~cm} \mathrm{yr}^{-1}$ ) (Lutz et al. 1994). Lamellibrachia cf. luymesi grows slowly, averaging $3 \mathrm{~cm} \mathrm{yr}^{-1}$ when small ( $<50 \mathrm{~cm}$ in length) and less than $1 \mathrm{~cm} \mathrm{yr}^{-1}$ when large (>150 cm in length) (Fisher et al. 1997, Bergquist et al. 2000). Seepiophila jonesi grows slower than L. cf. luymesi when small ( $<50 \mathrm{~cm}$ in length) and shows little evidence of growth when large (>50 cm in length) (Fisher et al. 1997). The size frequency distributions presented in this study provide additional support for the relative growth rates estimated for $L$. cf. luymesi and $S$. jonesi. In aggregations of smaller individuals, both species display similar size distributions, indicative of their similar growth rates when young. In aggregations of larger individuals, however, $S$. jonesi shows evidence of a strong decrease in growth rate as relatively few individuals exceed $50 \mathrm{~cm}$ in length even when the $L$. cf. luymesi in the same aggregation are $>1 \mathrm{~m}$ in length. However, a larger $S$. jonesi would need to maintain a minimum growth rate that is sufficient to prevent the burial of its anterior end by sediment. Direct staining or monitoring of $S$. jonesi in larger aggregations, hindered in this study by the morphology of the aggregations (disparity between the lengths of the 2 species) and nature of the staining device (limited depth of the staining dome), will be necessary to confirm this growth pattern.
That recruitment is temporally limited to the early stages of aggregation development indicates that within a single aggregation, individuals of both species are of a similar age. As shown here, the estimated mean ages and age ranges of the 2 species are very similar in aggregations of smaller individuals. The continued presence of Seepiophila jonesi in aggregations from which even the largest Lamellibrachia cf. luymesi were collected implies that $S$. jonesi lives at least as long as $L$. cf. luymesi. In fact, the observation of heavily-sedimented aggregations entirely composed of very large $S$. jonesi (Fig. 9), the lack of similar aggregations of only L. cf. luymesi, and the lack of young aggregations of only $S$. jonesi

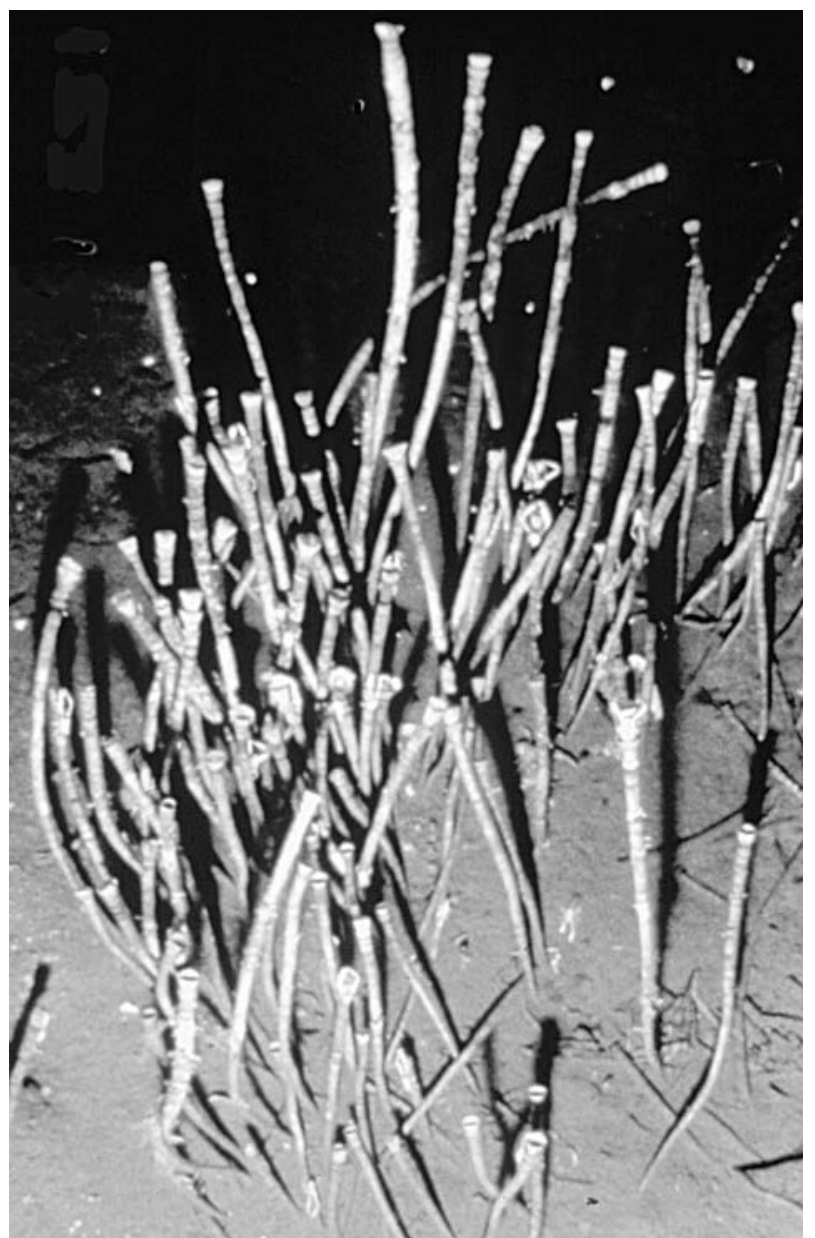

Fig. 9. Seepiophila jonesi. Heavily sedimented aggregation composed of only large $S$. jonesi. Photo: Ian R. MacDonald, Texas A\&M University, College Station, Texas, USA 
could indicate that aggregations of purely larger $S$. jonesi represent a late successional stage in vestimentiferan community development, one in which all $L$. cf. luymesi have perished. If this is the case, $S$. jonesi may outlive the very long-lived $L$. cf. luymesi.

The results of this study illustrate 2 elements crucial to understanding the establishment and persistence of vestimentiferan populations in hydrocarbon seep environments of the upper Louisiana slope. First, both species recruit roughly simultaneously to a substrate, but for neither does recruitment persist indefinitely to that substrate. Second, a slow growth rate and long life span are characteristic of both species. This apparently characteristic long life span probably stems from the recruitment dynamics of these vestimentiferans. Stearns (1992) suggests that a decrease in the 'value' of juveniles relative to the adults of a species would tend to favor the evolution of a long adult reproductive life span. The strict physiological dependence of seep vestimentiferans upon the sulfide in seep fluid and the patchy yet stable expression of seepage on the upper Louisiana slope suggest that, for vestimentiferans, suitable settlement substrate is spatially limited. The discontinuous size distributions of older aggregations further suggest that recruitment to a suitable environment is constrained in time as well. Reduced recruitment success resulting from the combined effects of spatial limitation and temporal constraint of vestimentiferan settlement sites would then tend to increase juvenile mortality rates (potentially both pre- or post-settlement) relative to adults, thus decreasing the value of juveniles relative to adults. Such forces would favor those individuals that can effectively capture resources and hold them for long periods of time over which reproduction may occur many times.

Acknowledgements. This work was supported by the Mineral Management Service project RFP-6899 and the Minerals Management Service, Gulf of Mexico Regional OCS Office through contract number 1435-01-96-СТ30813 and the NOAA National Undersea Research Program at the University of North Carolina, Wilmington. We would like to thank Emily Smith, Erin McMullin, John Freytag, Stephane Hourdez, Andrew Olaharski, and Jason Andras for sleepless assistance at sea and Tim McNelis, Sarah Howlett, J. T. Eckner, Hershel Tubbs, John Hunter, and Eileen McTague for assistance in the laboratory. Mark van Horn provided critical technical assistance both at sea and in the laboratory. Thanks also to Robert Carline, Joseph Keisecker, Eric Post, Katriona Shea and 4 anonymous reviewers for thoughtful discussion and comments on previous versions of this manuscript. Special thanks are due to Harbor Branch Oceanographic Institution, Chris Tietz and the captains, pilots and crew of the RV 'Seward Johnson' and the DSRV 'Johnson Sea Link'.

\section{LITERATURE CITED}

Aharon P, Fu B (2000) Microbial sulfate reduction rates and sulfur and oxygen isotope fractionations at oil and gas seeps in deepwater Gulf of Mexico. Geochim Cosmochim Acta 64:233-246

Anderson RK, Scalan RS, Parker PL, Behrens EW (1983) Seep oil and gas in Gulf of Mexico slope sediment. Science 222: 619-621

Arp AJ, Childress JJ, Fisher CR (1985) Blood gas transport in Riftia pachyptila. Bull Biol Soc Wash 6:289-300

Behrens WE (1988) Geology of a continental slope oil seep; northern Gulf of Mexico. Am Assoc Pet Geol Bull 72: 105-114

Bergquist DC, Williams FM, Fisher CR (2000) Longevity record for deep-sea invertebrate. Nature 403:400-500

Bright M, Kecheis H, Fisher CR (2000) An autoradiographic examination of carbon fixation, transfer and utilization in the Riftia pachyptila symbiosis. Mar Biol 136:621-632

Childress JJ, Arp AJ, Fisher CR (1984) Metabolic and blood characteristics of the hydrothermal vent tube-worm Riftia pachyptila. Mar Biol 83:109-124

Childress JJ, Fisher CR, Favuzzi JA, Kochevar RE, Sanders NK, Alayse AM (1991) Sulfide-driven autotrophic balance in the bacterial symbiont-containing hydrothermal vent tubeworm Riftia pachyptila Jones. Biol Bull 180:135-153

Corliss JB, Dymond J, Gordon LI, Edmond JM and 7 others (1979) Submarine thermal springs on the Galapagos Rift. Science 203:1073-1083

Fisher CR, Urcuyo IA, Simpkins MA, Nix E (1997) Life in the slow lane: growth and longevity of cold seep vestimentiferans. PSZN I: Mar Ecol 18:229-246

Freytag, JK, Girguis PR, Bergquist DC, Andras JP, Childress JJ, Fisher CR (2001) Sulfide acquisition by roots of seep tubeworms sustains net chemoautotrophy. Proc Natl Acad Sci USA 98:13408-13413

Gardiner SL, McMullin E, Fisher CR (2001) Seepiophila jonesi, a new genus and species of vestimentiferan tube worm (Annelida: Pogonophora) from hydrocarbon seep communities in the Gulf of Mexico. Proc Biol Soc Wash 114:694-707

Goffredi SK, Girguis PR, Childress JJ, Desaulniers NT (1999) Physiological functioning of carbonic anhydrase in the hydrothermal vent tubeworm Riftia pachyptila. Biol Bull 196:257-264

Hessler RR, Smithey WM, Boudrias MA, Keller CH, Lutz RA, Childress JJ (1988) Temporal change in megafauna at the Rose Garden hydrothermal vent (Galapagos Rift, eastern tropical Pacific). Deep-Sea Res 35:1681-1709

Julian D, Gaill F, Wood E, Arp AJ, Fisher CR (1999) Roots as a site of hydrogen sulfide uptake in the hydrocarbon seep vestimentiferan Lamellibrachia sp. J Exp Biol 202:2245-2257

Kennicutt II MC, Brooks JM, Bidigare RR, Fay RA, Wade TL, McDonald TJ (1985) Vent type taxa in a hydrocarbon seep region on the Louisiana slope. Nature 317:351-353

Lutz RA, Shank TM, Fornari DJ, Haymon RM, Lilley MD, von Damm KL, Desbruyeres D (1994) Rapid growth at deepsea vents. Nature 371:663-664

MacDonald IR, Boland GS, Baker JS, Brooks JM, Kennicutt MC II, Bidigare RR (1989) Gulf of Mexico hydrocarbon seep communities. II. Spatial distribution of seep organisms and hydrocarbons at Bush Hill. Mar Biol 101:235-247

MacDonald IR, Guinasso NL, Reilly JF, Brooks JM, Callender WR, Gabrielle SG (1990) Gulf of Mexico hydrocarbon seep communities. VI. Patterns in community structure and habitat. Geo-Mar Lett 10:244-252

Paull CK, Hecker B, Commeau R, Freeman-Lynde RP, Neumann C, Corso WP, Golubic S, Hook JE, Sikes E, Curray J (1984) Biological communities at the Florida Escarpment resemble hydrothermal vent taxa. Science 226:965-967

Rice WR (1989) Analyzing tables of statistical tests. Evolution $43: 223-225$ 
Sarrazin J, Juniper SK (1999) Biological characteristics of a hydrothermal edifice mosaic community. Mar Ecol Prog Ser 185:1-19

Sassen R, Roberts HH, Aharon P, Larkin J, Chinn EW, Carney R (1993) Chemosynthetic bacterial mats at cold hydrocarbon seeps, Gulf of Mexico continental slope. Org Geochem 20:77-89

Scott KM, Fisher CR (1995) Physiological ecology of sulfide metabolism in hydrothermal vent and cold seep vesicomyid clams and vestimentiferan tube worms. Am Zool 35:102-111

Shank TM, Fornari DJ, von Damm KL, Lilley MD, Haymon RM, Lutz RA (1998) Temporal and spatial patterns of biological community development at nascent deep-sea

Editorial responsibility: Otto Kinne (Editor), Oldendorf/Luhe, Germany hydrothermal vents $\left(9^{\circ} 50^{\prime} \mathrm{N}\right.$, East Pacific Rise). Deep-Sea Res 45:465-515

Simpkins MA (1994) Ecology of hydrocarbon seep vestimentiferans: growth andcondition in a variable environment. Masters thesis, Pennsylvania State University, State College, PA

Stearns SC (1992) The evolution of life histories. Oxford University Press, New York

Tsurumi M, Tunnicliffe V (2001) Characteristics of a hydrothermal vent assemblage on a volcanically active segment of Juan de Fuca Ridge, northeast Pacific. Can J Fish Aquat Sci 58:530-542

Tunnicliffe V (1991) The biology of hydrothermal vents: ecology and evolution. Oceanogr Mar Biol Annu Rev 29:319-407

Submitted: July 23, 2001; Accepted: May 13, 2002

Proofs received from author(s): September 9, 2002 